\title{
REFERENCES FOR PRINTED WORKS CITED
}

Adams, R., ed. (1989), Desiderius Erasmus, The Praise of Folly and Other Writings (New York)

Andrews, F. (2006), The Other Friars: The Carmelite, Augustinian, Sack and Pied Friars in the Middle Ages (Woodbridge)

Aston, M. (1984), “Caim's Castles”: poverty, politics and disendowment', in The Church, Politics and Patronage in the Fifteenth Century, ed. R. B. Dobson (Gloucester), 45-81

Baskerville, G. (1937), English Monks and the Suppression of the Monasteries (London)

Bell, D. (1995), What Nuns Read: Books and Libraries in Medieval English Nunneries (Kalamazoo)

- (1999), 'Monastic libraries: 1400-1557', in The Cambridge History of the Book in Britain, vol. III: 1400-1557, ed. L. Hellinga and J. Trapp (Cambridge), 229-54

Bernard, G. (2005), The King's Reformation: Henry VIII and the Remaking of the English Church (New Haven)

Bond, C. J. (2001), 'Monastic water management in Great Britain: a review', in Monastic Archaeology: Papers on the Study of Medieval Monasteries, ed. G. Keevill, M. Aston and T. Hall (Oxford), 88-136

Bonney, M. (1990), Lordship and the Urban Community: Durham and its Overlords 1250-1540 (Cambridge)

Bowers, R. (1994), 'The musicians of the lady chapel of Winchester Cathedral Priory, 1402-1539', Journal of Ecclesiastical History, 45, 210-37

— (1999), 'The almonry schools of the English monasteries, c. 1265-1540', in Monasteries and Society in Medieval Britain, ed. B. Thompson (Stamford), $177-222$

Bowker, M. (1981), The Henrician Reformation: The Diocese of Lincoln under John Longland 1521-1547 (Cambridge)

Brooke, C. (2003), The Age of the Cloister: The Story of Monastic Life in the Middle Ages (Stroud)

Brown, A. (1995), Popular Piety in Late Medieval England: The Diocese of Salisbury 1250-1550 (Oxford)

Burgess, C. (1988), “A fond thing vainly invented”: an essay on Purgatory and pious motive in later medieval England', in Parish, Church and People, ed. S. Wright (London), 56-84 
- (1990), 'Late-medieval wills and pious convention: testamentary evidence reconsidered', in Profit, Piety and the Professions in Later Medieval England, ed. M. Hicks (Gloucester), 14-33

- (2005), 'St George's College, Windsor: context and consequence', in St George's Chapel Windsor in the Fourteenth Century, ed. N. Saul (Woodbridge), 63-96

Cassidy-Welch, M. (2001), Monastic Spaces and their Meanings: ThirteenthCentury Cistercian Monasteries (Turnhout)

Catto, J. (1985), 'Religion and the English nobility in the later fourteenth century', in History and Imagination: Essays in Honour of H. R. Trevor-Roper, ed. H. Lloyd Jones, V. Pearl and B. Worden (London), 43-55

Clark, J. (2000a), 'Reformation and reaction at St Albans Abbey, 1530-58', English Historical Review, 115, 297-328

- (2000b), 'Selling the holy places: monastic efforts to win back the people in fifteenth-century England', in Social Attitudes and Political Structures in the Fifteenth Century, ed. T. Thornton (Stroud), 13-32

_ (2002) 'The religious orders in pre-Reformation England', in The Religious Orders in Pre-Reformation England, ed. J. Clark (Woodbridge), 3-33

- (2004), A Monastic Renaissance at St Albans: Thomas Walsingham and his Circle, c. 1350-1440 (Oxford)

Clay, R. M. (1914), The Hermits and Anchorites of England(London)

Cobbett, W. (1827), A History of the Protestant Reformation (London)

Coldstream, N. (1986), 'Cistercian architecture from Beaulieu to the Dissolution', in Cistercian Art and Architecture in the British Isles, ed. C. Norton and D. Park (Cambridge), 139-59

Colvin, H. (1951), The White Canons in England(Oxford)

Coppack, G. (2002), 'The planning of Cistercian monasteries in the later middle ages: the evidence from Fountains, Rievaulx, Sawley and Rushen', in The Religious Orders in Pre-Reformation England, ed. J. Clark (Woodbridge), 197-209

Coppack, G. and M. Aston (2003), Christ's Poor Men: The Carthusians in England (Stroud)

Coulton, G. G. (1923-50) Five Centuries of Religion, 4 vols (London)

Cross, C. (1988), 'Monasticism and society in the diocese of York, 1520-1540', Transactions of the Royal Historical Society, 5th series, 38, 131-45

- (2002), 'Yorkshire nunneries', in The Religious Orders in Pre-Reformation England, ed. J. Clark (Woodbridge), 145-54

Davis, V. (1993), William Waynflete, Bishop and Educationalist (Woodbridge)

Dickens, A. G. (1987), 'The shape of anti-clericalism and the English Reformation', in Politics and Society in Reformation Europe, ed. E. Kouri and T. Scott (Basingstoke), 379-410 
Dickinson, J. C. (1950), The Origins of the Austin Canons and their Introduction into England (London)

Dobson, R. B. (1973), Durham Priory 1400-1450 (Cambridge)

— (1992), 'The religious orders 1370-1540', in The History of the University of Oxford, vol. II: Late Medieval Oxford, ed. J. Catto and R. Evans (Oxford), 539-80

- (1995), 'The monks of Canterbury in the later middle ages, 1220- 1540', in A History of Canterbury Cathedral, ed. P. Collinson, N. Ramsay and M. Sparks (Oxford), 69-153

- (1999a), 'The monastic orders in late medieval Cambridge', in The Medieval Church: Universities, Heresy and the Religious Life, ed. P. Biller and R. B. Dobson, Studies in Church History, Subsidia 11 (Woodbridge), 239-69

— (1999b), 'English and Welsh monastic bishops: the final century, 14331533', in Monasteries and Society in Medieval Britain, ed. B. Thompson (Stamford), 348-67

— (2003), “The clergy are well lodged”: the transformation of the cathedral precinct at late medieval Durham', in The Medieval English Cathedral, ed. J. Backhouse (Donington), 23-40

Dodds, B. (2004), 'Estimating arable output using Durham Priory tithe receipts, 1351-1450', Economic History Review, 57, 245-85

Doyle, A. I. (1988), 'The printed books of the last monks of Durham', The Library, 6th series, 10, 203-19

— (1990), 'Book production by the monastic orders in England (c.13751530): assessing the evidence', in Medieval Book Production: Assessing the Evidence, ed. L. Brownrigg (Los Altos Hills), 1-19

Duffy, E. (1992), The Stripping of the Altars: Traditional Religion in England, $1400-1580$ (New Haven)

Dutton, M. (1999), 'Chaucer's two nuns', in Monasteries and Society in Medieval Britain, ed. B. Thompson (Stamford), 296-311

Dyer, C. (2005), An Age of Transition? Economy and Society in England in the Later Middle Ages (Oxford)

Ellis, R. (1997), 'Further thoughts on the spirituality of Syon Abbey', in Mysticism and Spirituality in Medieval England, ed. W. Pollard and R. Boenig (Woodbridge), 219-43

Emery, A. (1996-2006), Greater Medieval Houses of England and Wales, 1300-1500, 3 vols (Cambridge)

Erler, M. (2002), Women, Reading and Piety in Late Medieval England (Cambridge)

Evennett, H. (1958), 'The new orders', in The New Cambridge Modern History, vol. II: The Reformation 1520-1559, ed. G. Elton (Cambridge), 275-300

Farnhill, K. (2006), 'The guild of the Annunciation of the Blessed Virgin Mary and the priory of St Mary in Walsingham', in The Parish in Late Medieval England, ed. C. Burgess and E. Duffy (Donington), 129-45 
Field, S. (2002), 'Devotion, discontent and the Henrician Reformation: the evidence of Robin Hood stories', Journal of British Studies, 41, 6-22

Fleming, P. (1984), 'Charity, faith, and the gentry of Kent 1422-1529', in Property and Politics: Essays in Later Medieval English History, ed. A. Pollard (Gloucester), 36-58

- (2000), 'Conflict and urban government in later medieval England: St Augustine's Abbey and Bristol', Urban History, 27, 325-43

Froude, J. A. (1867-83), Short Studies on Great Subjects: Series I-IV(London)

Gasquet, F. A. (1893), Henry VIII and the English Monasteries, 5th edn (London)

Gilchrist, R. (1994), Gender and Material Culture: The Archaeology of Religious Women (London)

- (2005), Norwich Cathedral Close: The Evolution of the English Cathedral Landscape (Woodbridge)

Gilchrist, R. and B. Sloane (2005), Requiem: The Medieval Monastic Cemetery in Britain (London)

Gillespie, V. (1989), 'Cura pastoralis in deserto', in De Cella in Saeculum: Religious and Secular Life and Devotion in Late Medieval England, ed. M. Sargent (Cambridge), 161-81

— (1999), 'Dial M for mystic: mystical texts in the library of Syon Abbey and the spirituality of the Syon brethren', in The Medieval Mystical Tradition in England, Ireland and Wales: Exeter Symposium VI, ed. M. Glasscoe (Cambridge), 241-68

- (2000) 'The book and the brotherhood: reflections on the lost library of Syon Abbey', in The English Medieval Book, ed. A. Edwards, V. Gillespie and R. Hanna (London), 195-208

- (2002), 'Syon and the New Learning', in The Religious Orders in Pre-Reformation England, ed. J. Clark (Woodbridge), 75-95

Golding, B. (1995), Gilbert of Sempringham and the Gilbertine Orderc. 1130-c. 1300 (Oxford)

Graham, R. (1929), English Ecclesiastical Studies (London)

Gransden, A. (1975), 'A democratic movement in the abbey of Bury St Edmunds in the late twelfth and early thirteenth centuries', Journal of Ecclesiastical History, 26, 25-39

Greatrex, J. (1994), 'The English cathedral priories and the pursuit of learning in the later middle ages', Journal of Ecclesiastical History, 45, 396-411

- (2002), 'After Knowles: recent perspectives in monastic history', in The Religious Orders in Pre-Reformation England, ed. J. Clark (Woodbridge), $35-47$

Greene, J. (1989), Norton Priory (Cambridge)

Grenville, J. (1997), Medieval Housing (London) 
Gribbin, J. (2001), The Premonstratensian Order in Late Medieval England (Woodbridge)

Haigh, C. (1975), Reformation and Resistance in Tudor Lancashire (Cambridge)

— (1987) 'Anticlericalism and the English Reformation', in The English Reformation Revised, ed. C. Haigh (Cambridge), 56-74

- (1993), English Reformations: Religion, Politics and Society under the Tudors (Oxford)

Haines, R. (2003), 'Regular clergy and the episcopate in the provinces of Canterbury and York during the later middle ages', Revue Bénédictine, 113, $407-47$

Hanna, R. (2000), 'Augustinian canons and Middle English literature', in The English Medieval Book, ed. A. Edwards, V. Gillespie and R. Hanna (London), $27-42$

Harper-Bill, C. (1985), 'The labourer is worthy of his hire? Complaints about diet in late medieval English monasteries', in The Church in Pre-Reformation Society, ed. C. Barron and C. Harper-Bill (Woodbridge), 95-107

- (1988), 'Dean Colet's Convocation sermon and the pre-Reformation Church in England', History, 73, 191-210

Harper-Bill, C. and C. Rawcliffe (2004), 'The religious houses', in Medieval Norwich, ed. C. Rawcliffe and R. Wilson (London), 73-119

Harrison, F. Ll. (1963), Music in Medieval Britain, 2nd edn (London)

Harvey, B. (1977), Westminster Abbey and its Estates in the Middle Ages (Oxford)

— (1993), Living and Dying in England 1100-1540: The Monastic Experience (Oxford)

- (2002), 'A novice's life at Westminster Abbey in the century before the Dissolution', in The Religious Orders in Pre-Reformation England, ed. J. Clark (Woodbridge), 51-73

Hatcher, J. (1986), 'Mortality in the fifteenth century: some new evidence', Economic History Review, 2nd series, 39, 19-38

- (1996), 'The great slump of the mid-fifteenth century', in Progress and Problems in Medieval England, ed. R. Britnell and J. Hatcher (Cambridge), 237-72

Heal, F. (1990), Hospitality in Early Modern England(Oxford)

Heale, M. (2004a), The Dependent Priories of Medieval English Monasteries (Woodbridge)

- (2004b), 'Dependent priories and the closure of monasteries in late medieval England, 1400-1535', English Historical Review, 119, 1-26

- (2006) 'Monastic-parochial churches in late medieval England', in The Parish in Late Medieval England, ed. C. Burgess and E. Duffy (Donington), 54-77

- (2007), 'Training in superstition? Monasteries and popular religion in 
late medieval and Reformation England', Journal of Ecclesiastical History, $58,417-37$

— (2008a), “Not a thing for a stranger to enter upon”: the selection of monastic superiors in late medieval and early Tudor England', in Monasteries and Society in the British Isles in the Later Middle Ages, ed. J. Burton and K. Stöber (Woodbridge), 51-68

- (2008b), 'Colleges and monasteries in late medieval England', in The Late Medieval English College and its Context, ed. C. Burgess and M. Heale (York), $67-86$

Heath, P. (1984), 'Urban piety in the later middle ages: the evidence of Hull wills', in The Church, Politics and Patronage in the Fifteenth Century, ed. R. B. Dobson (Gloucester), 209-34

Hoyle, R. (1995), 'The origins of the Dissolution of the monasteries', The Historical Journal, 38, 275-305

Hudson, A. (1988), The Premature Reformation: Wycliffite Texts and Lollard History (Oxford)

Huizinga, J. (1924), The Waning of the Middle Ages (London)

Hume, D. (1780), The History of England from the Invasion of Julius Caesar to the Revolution in 1688, 8 vols (Dublin)

Jones, M. and M. Underwood (1992), The King's Mother. Lady Margaret Beaufort, Countess of Richmond and Derby (Cambridge)

Kaartinen, M. (2002), Religious Life and English Culture in the Reformation (Basingstoke)

Kermode, J. (1998), Medieval Merchants: York, Beverley and Hull in the Later Middle Ages (Cambridge)

Kershaw, I. (1973), Bolton Priory: The Economy of a Northern Monastery 1286-1325 (Oxford)

Knowles, D. (1948-59), The Religious Orders in England, 3 vols (Cambridge)

— (1963), The Monastic Order in England: A History of its Development from the Times of St Dunstan to the Fourth Lateran Council, 940-1216, 2nd edn (Cambridge)

- (1969), Christian Monasticism (London)

Knowles, D. and R. N. Hadcock (1971), Medieval Religious Houses: England and Wales, 2nd edn (London)

Lawrence, C. H. (2000), Medieval Monasticism: Forms of Religious Life in Western Europe in the Middle Ages, 3rd edn (London)

Lee, P. (2001), Nunneries, Learning and Spirituality in Late Medieval English Society: The Dominican Priory of Dartford (Woodbridge)

Lovatt, R. (1992), 'The library of John Blacman and contemporary Carthusian spirituality', Journal of Ecclesiastical History, 43, 195-230

Luxford, J. (2005), The Art and Architecture of English Benedictine Monasteries, 1300-1540: A Patronage History (Woodbridge) 
MacCulloch, D. (1996), Thomas Cranmer: A Life (New Haven)

Makowski, E. (1999), Canon Law and Cloistered Women: Periculoso and its Commentators, 1298-1545 (Washington DC)

Mann, J. (1973), Chaucer and Medieval Estates Satire: The Literature of Social Classes and the General Prologue to the Canterbury Tales (Cambridge)

Marshall, P. (2003), Reformation England 1480-1642 (London)

- (2006), 'Anticlericalism revested? Expressions of discontent in early Tudor England', in The Parish in Late Medieval England, ed. C. Burgess and E. Duffy (Donington), 365-80

Martin, J. (1998), 'Leadership and priorities in Reading during the Reformation', in The Reformation in English Towns, 1500-1640, ed. P. Collinson and J. Craig (Basingstoke), 113-29

Matthew, D. (1962), The Norman Monasteries and their English Possessions (Oxford)

Mayer, T., ed. (1989), Thomas Starkey: A Dialogue between Pole and Lupset, Camden Society, 4th series, 37

Morris, R. (1979), Cathedrals and Abbeys of England and Wales: The Building Church, 600-1540 (London)

Myers, A., ed. (1969), English Historical Documents, IV, 1327-1485 (London)

Newman, C. (2000), 'Employment on the estates of the priory of Durham, 1494- 1519: the priory as an employer', Northern History, 36, 43-58

Oakley, F. (1979), The Western Church in the Later Middle Ages (Ithaca, NY)

Olin, J. (1969), The Catholic Reformation: Savonarola to Ignatius Loyola (New York)

Oliva, M. (1998), The Convent and the Community in Late Medieval England: Female Monasteries in the Diocese of Norwich, 1350-1540 (Woodbridge)

Orme, N. (2006), Medieval Schools from Roman Britain to Renaissance England (New Haven)

— (2008), The Victoria History of the County of Cornwall, II: Religious History to 1559 (London)

Pantin, W. A. (1944), 'The monk-solitary of Farne: a fourteenth-century English mystic', English Historical Review, 59, 162-86

Parish, H. (2005), Monks, Miracles and Magic: Reformation Representations of the Medieval Church (London)

Pearsall, D. (2001), "If heaven be on this earth, it is in cloister or in school": the monastic ideal in later medieval English literature', in Pragmatic Utopias: Ideals and Communities, 1200-1630, ed. R. Horrox and S. Rees Jones (Cambridge), 11-25

Platt, C. (1984), The Abbeys and Priories of Medieval England(London)

Power, E. (1922), Medieval English Nunneries c. 1275 to 1535 (Cambridge) 
Raban, S. (1982), Mortmain Legislation and the English Church 1279-1500 (Cambridge)

Renna, T. (1987), 'Wyclif's attacks on the monks', in From Ockham to Wyclif, ed. A. Hudson and M. Wilks, Studies in Church History, Subsidia 5 (Oxford), 267-80

Rhodes, J. (1993), 'Syon Abbey and its religious publications in the sixteenth century', Journal of Ecclesiastical History, 44, 11-25

Riley, H., ed. (1863-64), Thomae Walsingham, quondam monachi S. Albani, Historia Anglicana, Rolls Series, 2 vols, no. 28

Robinson, D. (1980), The Geography of Augustinian Settlement in Medieval England and Wales, British Archaeological Reports, British Series, 80

Rollason, L. (1999), 'The Liber Vitae of Durham and lay association with Durham Cathedral Priory in the later middle ages', in Monasteries and Society in Medieval Britain, ed. B. Thompson (Stamford), 277-95

Roper, S. (1993), Medieval English Benedictine Liturgy: Studies in the Formation, Structure, and Content of the Monastic Votive Office, c. 950-1540 (New York and London)

Rosenthal, J. (1972), The Purchase of Paradise (London)

Rushton, N. (2001), 'Monastic charitable provision in Tudor England: quantifying and qualifying poor relief in the early sixteenth century', Continuity and Change, 16, 9-44

Sargent, M. (1976), 'The transmission by the English Carthusians of some late medieval spiritual writings', Journal of Ecclesiastical History, 2, 225-40

Savine, A. (1909), English Monasteries on the Eve of the Dissolution (Oxford)

Scase, W. (1989), Piers Plowman and the New Anticlericalism (Cambridge)

Schmidt, A., ed. (1978), William Langland, The Vision of Piers Plowman: A Complete Edition of the B-Text (London)

Schofield, A. (1966), 'The second English delegation to the Council of Basel', Journal of Ecclesiastical History, 17, 29-64

Shagan, E. (2003), Popular Politics and the English Reformation (Cambridge)

Smith, D. (2006), 'The phantom prior of Mount Grace', Monastic Research Bulletin, 12, 46-9

Spear, V. (2005), Leadership in Medieval English Nunneries (Woodbridge)

Stöber, K. (2007), Late Medieval Monasteries and their Patrons: England and Wales, c. 1300-1540 (Woodbridge)

Swanson, R. (1989), Church and Society in Late Medieval England (Oxford)

- (2002), 'Mendicants and confraternity in late medieval England', in The Pre-Reformation Church in England, ed. J. Clark (Woodbridge), 121-41

- (2004), 'Books of brotherhood: registering fraternity and confraternity in late medieval England', in The Durham Liber Vitae and its Context, ed. D. Rollason, A. J. Piper, M. Harvey and L. Rollason (Woodbridge), 233-46 
Tanner, N. (1984), The Church in Late Medieval Norwich, Pontifical Institute of Medieval Studies, Studies and Texts LXVI (Toronto)

Thompson, A. H., ed. (1914-29), Visitations of Religious Houses in the Diocese of

Lincoln, 1420-49, Lincoln Record Society, 3 vols, nos 7, 14, 21

— ed. (1940-47), Visitations in the Diocese of Lincoln, 1517-31, Lincoln Record Society, 3 vols, nos 33, 35, 37

Thompson, B. (1994a) 'The laity, the alien priories, and the redistribution of ecclesiastical property', in England in the Fifteenth Century, ed. N. Rogers (Stamford), 19-41

(1994b), 'Monasteries and their patrons at foundation and Dissolution', Transactions of the Royal Historical Society, 6th series, 4, 103-26

— (1999), 'Introduction: monasteries and medieval society', in Monasteries and Society in Medieval Britain, ed. B. Thompson (Stamford), 1-33

- (2002), 'Monasteries, society and reform in late medieval England', in The Religious Orders in Pre-Reformation England, ed. J. Clark (Woodbridge), $165-95$

Thompson, E. M. (1930), The Carthusian Order in England (London)

Thompson, M. (2001), Cloister, Abbot and Precinct in Medieval Monasteries (Stroud)

Thomson, J. A. F. (1965), 'Piety and charity in late medieval London', Journal of Ecclesiastical History, 16, 178-95

- (1993), The Early Tudor Church and Society 1485-1529 (Harlow)

Threlfall-Holmes, M. (2005), Monks and Markets: Durham Cathedral Priory $1460-1520$ (Oxford)

Tillotson, J. (1989), Marrick Priory: A Nunnery in Late Medieval Torkshire, Borthwick Paper, no. 75

Vauchez, A. (1997), Sainthood in the Later Middle Ages (Cambridge)

Watkins, A. (1994), 'Merevale Abbey in the late 1490s', Warwickshire History, $9,87-104$

— (1996), 'Maxstoke Priory in the fifteenth century: the development of an estate economy in the Forest of Arden', Warwickshire History, 10, 3-18

Webber, T. (1997), 'Latin devotional texts and the books of the Augustinian canons of Thurgarton Priory and Leicester Abbey in the late middle ages', in Books and Collectors 1200-1700: Essays Presented to Andrew Watson, ed. J. Carley and C. Tite (London), 27-41

Youings, J. (1971), The Dissolution of the Monasteries (London)

- (1990), 'The monasteries', in Rural Society: Landowners, Peasants and Labourers 1500-1750, ed. C. Clay (Cambridge), 71-120

Zarnecki, G. (1972), The Monastic Achievement(London) 